\title{
THE MOST EFFICIENT TECHNOLOGY OF WASHING AND DEGREASING PARTS AFTER CNC MACHINING
}

\author{
${ }^{1}$ Andrea SIKOROVÁ, ${ }^{2}$ Martin LAMPA, ${ }^{3}$ Zdeněk MARTíNEK \\ 1,2,3VSB - Technical University of Ostrava, Ostrava, Czech Republic, EU, \\ andrea.sikorova@vsb.cz, martin.lampa@vsb.cz, zdenek.martinek.st@vsb.cz
}

https://doi.org/10.37904/metal.2019.987

\begin{abstract}
The objective of this article is to compare and evaluate the most suitable washing technology of cleaning and degreasing machined parts after CNC machining, based on analysis of technological and economic criteria. Based on these criteria, costs of low-quality products are eliminated, production costs of manufactured parts are reduced, and the enterprise reaches higher profit. Increasing of quality of products and services is accompanied by the necessity of permanent investments into new production technologies that would move quality of products to the limit where they maintain or increase profitability of manufactured products, attract new customers, and thus bring profit to the company. Permanently increasing quality of products and services is understood as a never-ending cycle.
\end{abstract}

Keywords: Technology; criteria; economic indices; multi-criteria decision making

\section{INTRODUCTION}

The choice of supplier of the washing technology for degreasing parts after CNC machining is an important element in the process of modifying machined parts, particularly in precise manufacturing. The objective of the contribution is to set criteria for appropriate and efficient choice of washing technology, to analyze and compare these criteria with the aim of selecting the most suitable and efficient washing and degreasing technology that would also bring reduced costs. Subsequently, it is necessary to choose a supplier and establish the procedure of purchasing and implementation of the washing technology into a metallurgical enterprise [1]. The choice of the washing technology for degreasing parts after CNC machining will be solved and evaluated in the following steps: description of current state of washing components after CNC machining; specification of requirements for the washing technology; determination of criteria crucial for choice of the washing technology; their evaluation based on economic indices and multi-criteria decision making; choice of the best variant.

\section{PROCESS OF PURCHASE PLANNING}

The process of purchase planning represents a process that, on one hand, includes tasks realized on the purchase market the purpose of which is to provide production material, equipment and services for internal customers in the production, research/development, auxiliary and service processes, and in administration [2]. This requires having at disposal tools based on which it is possible to analyze requirements, their exact specification, to look for potential suppliers, to assess them, all this with the aim of establishing long-term positive relations with a supplier [3]. The process of purchase can be divided into the following steps [4]: 1. Specification of purchase requirements; 2 . Decision on purchase and specification of the product or material; 3. Examination of offers, finding of primary information on potential suppliers; 4 . Selection of the supplier; 5 . Evaluation of offers, making out of purchase order; 6 . Receipt of material or product; 7 . Financial settlement; 8. Assessment of the supplier. A very important step is selection and choice of the most advantageous supplier and therewith connected technology. The outcome is a group of potential suppliers capable of providing required material of required quality, quantity, using required technological procedures and technologies. Based on these requirements, it is possible to specify criteria of choice and to evaluate them also from the viewpoint of costs, and to assess them using methods of investment decision making. 
Investment decision making is, indisputably, the most important kind of decision within an enterprise. Its purpose is to assess and decide, based on evaluation, on possible realization of the investment. First, it is necessary to define quantifiable characteristics for assessment of the investment, to assign, specify and evaluate the investment project in order to determine limit values for rejecting or approving the investment project. Two methods used in financial evaluation of investments are differentiated by the way of taking into account the factor of time; they are divided into: static methods that do not take into account the factor of time, dynamic methods that take into account the factor of time [5]. On the other hand, the methods of multi-criteria decision making are based on assessment of finite number of variants based on selected qualitative or quantitative criteria [6]. In deciding on variants where quantitative information can be utilized, it is appropriate to apply methods based on multi-criteria function of benefit or on a compromise criterion. One of these methods is also method VIKOR [7]. For example [8] applied AHP/ANP approach on application MCDM on investment decision making. However, when dealing with quantitative criteria methods like VIKOR perform better.

\section{SELECTION OF WASHING LINE USING INVESTMENT AND MULTI-CRITERIA DECISION MAKING}

\subsection{Description of current state in process of washing of components}

In a metallurgical enterprise, final assembly of products is separated from the rest of production. Possible contamination during final assembly can arise from contaminated components that have not been properly pre-treated and/or cleaned for final assembly [9]. The cleaning of parts means their washing in an industrial washing machine. Based on thorough analysis of the state of washing baths of industrial washing machines in a metallurgical enterprise, empirically obtained data on the washing process, and outlet cleanness of components, the enterprise has come to the fact that some of industrial washing machines are no more suitable for the process. Their operation is costly in relation to required cleanness. In particular, this concerns replacement of existing washing machine KERMAD K3V. Industrial washing machine KERMAD K3V is used for washing large steel components after CNC machining and welding; it was made to order in 2002 (hereinafter KERMAD). Washing technology KERMAD is based on a pressure spray principle. Surface of parts is sprayed with a hot degreasing liquid while the basket with parts rotates around its vertical axis. The washing technology is of single-chamber type, i.e. just one washing bath is at disposal for the washing process. The bath for rinsing and drying of components is missing. The choice of replacement of this washing machine is a subject of the following analysis. Requirements for the new washing technology can be divided into: technical parameters, operation parameters, operation-economic parameters, and washing efficiency of the new washing technology. In this respect, two approaches have been applied and compared: multi-criteria evaluation using method VIKOR and investment decision making. Two variants of new washing machines have arisen out of contacts with the existing suppliers, i.e. firms KERMAD and IMTOS, Ltd. (hereinafter IMTOS). Firm KERMAD is a supplier of the washing technology to be now replaced. Firm IMTOS is a supplier of washing technology Mafac. The third variant came out from the contact with the new supplier. This is firm SUMMA Ltd. (hereinafter SUMMA).

\subsection{Evaluation of industrial washing machines using multi-criteria method VIKOR}

Multi-criteria method VIKOR has been chosen for evaluation of individual industrial washing machines. The method is based on linear normalization of data and complex comparison of variants. Variants are assessed with respect to vicinity to an ideal variant. Unlike, for instance, method TOPSIS, one can use the so-called compromise criterion, i.e. possibility of selecting between the effect of overall $\left(S_{j}\right)$ or maximum $\left(R_{j}\right)$ evaluation of variants in calculating score $Q_{j}$. Method VIKOR (Vlse Criterijumska Optimizacija Kompromisno Resenje) [7] was first published in 1998 as a method for solving multi-criteria optimization of complex systems. Using this method, one can set up a compromise order, compromise solution, and intervals of stability of preferences for given weights. The method is based on calculation of distance to an ideal solution. The procedure of method 
VIKOR can be described in the following steps. Determination of the best $f_{i}^{*}$, and the worst $f_{i}^{-}$values of all criteria, $i=1,2, \ldots, n$. Values $S j$ and $R j, j=1,2, \ldots, k$, are calculated according to the Equations 1 and 2.

$$
S_{j}=\sum_{i=1}^{n} w_{i} \frac{\left(f_{i}^{*}-f_{i j}\right)}{\left(f_{i}^{*}-f_{i j}^{-}\right)}, \quad R_{j}=\max _{i}\left[w_{i} \frac{\left(f_{i}^{*}-f_{i j}\right)}{\left(f_{i}^{*}-f_{i j}^{-}\right)}\right]
$$

where $w_{i}$ is normalized weight of $i$-th criterion. The following step is calculation of values $Q_{j}, j=1,2, \ldots, j$, according to the Equation 3.

$$
Q_{j}=v \frac{\left(S_{j}-S^{*}\right)}{\left(S^{-}-S^{*}\right)}+(1-v) \frac{\left(R_{j}-R^{*}\right)}{\left(R^{-}-R^{*}\right)},
$$

where, $v$ is weight with which the decision maker can influence strength of a given comprehensive criterion, i.e. $S_{j}(1)$ or $R_{j}(2)$. In the first phase of evaluation, two new variants were compared, namely washing machines MCL (SUMMA) and PT-PRO-3-HP-MV2A (IMTOS), see Table 1. Weight was expert-determined on the scale 0 - 3. As criteria of all three variants could not be compared within all criteria, the variants have been evaluated separately.

\begin{tabular}{|c|c|c|c|c|c|c|c|c|c|}
\hline Machine designation & Unit & SUMMA & IMTOS & $\begin{array}{l}\text { Min/ } \\
\text { Max }\end{array}$ & $\mathbf{f}^{*} \mathbf{j}$ & $f-j$ & Weight & $\begin{array}{c}\mathbf{S j} \\
\text { (SUMMA) }\end{array}$ & $\begin{array}{c}\mathbf{S j} \\
\text { (IMTOS) }\end{array}$ \\
\hline Width & $(\mathrm{mm})$ & 2300 & 1930 & Min & 1930 & 2300 & 2 & 2 & 0 \\
\hline Depth & $(\mathrm{mm})$ & 2100 & 1345 & Min & 1345 & 2100 & 2 & 2 & 0 \\
\hline Height & $(\mathrm{mm})$ & 2520 & 2685 & Min & 2520 & 2685 & 2 & 0 & 2 \\
\hline Weight of machine & $(\mathrm{kg})$ & 750 & 900 & Min & 750 & 900 & 2 & 0 & 2 \\
\hline Length of working space & $(\mathrm{mm})$ & 1150 & 1080 & Max & 1150 & 1080 & 2 & 0 & 2 \\
\hline Height of working space & $(\mathrm{mm})$ & 800 & 700 & Max & 800 & 700 & 2 & 0 & 2 \\
\hline Maximum weight of parts & $(\mathrm{kg})$ & 300 & 700 & Max & 700 & 300 & 3 & 3 & 0 \\
\hline Degreasing bath & (I) & 300 & 250 & Max & 300 & 250 & 2 & 0 & 2 \\
\hline Temperature of bath & $\left({ }^{\circ} \mathrm{C}\right)$ & 60 & 65 & Max & 65 & 60 & 2 & 2 & 0 \\
\hline Degreasing pressure & (bar) & 5.5 & 4.6 & Max & 6 & 5 & 3 & 0 & 3 \\
\hline Pump output & $(1 / \min )$ & 150 & 263 & Max & 263 & 150 & 3 & 3 & 0 \\
\hline Power input of heating bodies & $(\mathrm{kW})$ & 12 & 9 & Min & 9 & 12 & 2 & 2 & 0 \\
\hline Filtration, $\mu \mathrm{m}$ & $(\mu \mathrm{m})$ & 5 & 25 & Min & 5 & 25 & 3 & 0 & 3 \\
\hline Rinsing bath & (l) & 300 & 250 & Max & 300 & 250 & 3 & 0 & 3 \\
\hline Temperature of bath & $\left({ }^{\circ} \mathrm{C}\right)$ & 60 & 65 & Max & 65 & 60 & 2 & 2 & 0 \\
\hline Rinsing pressure & (bar) & 3.2 & 4.2 & Max & 4.2 & 3.2 & 3 & 3 & 0 \\
\hline Output of pumps & $(1 / \min )$ & 150 & 186 & Max & 186 & 150 & 3 & 3 & 0 \\
\hline Power input of heating bodies & $(\mathrm{kW})$ & 12 & 9 & Min & 9 & 12 & 2 & 2 & 0 \\
\hline Drying temperature & $\left({ }^{\circ} \mathrm{C}\right)$ & 120 & 80 & Max & 120 & 80 & 2 & 0 & 2 \\
\hline Power input of drying chamber & $(\mathrm{kW})$ & 13.5 & 9 & Min & 9 & 13.5 & 2 & 2 & 0 \\
\hline Time of heating up of degreasing bath & $\min$ & 73.39 & 81.55 & $\min$ & 73.39 & 81.55 & 3 & 0 & 3 \\
\hline Time of heating up of rinsing bath & $\min$ & 73.39 & 81.55 & $\min$ & 73.39 & 81.55 & 3 & 0 & 3 \\
\hline Price of heating of degreasing bath & CZK & 58.72 & 48.93 & $\min$ & 48.93 & 58.72 & 3 & 3 & 0 \\
\hline Price of heating of rinsing bath & CZK & 78.72 & 48.94 & $\min$ & 48.94 & 78.72 & 3 & 3 & 0 \\
\hline
\end{tabular}

Table 1 Parameters of degreasing function of three variants [own study] 
The result of calculation of values $Q_{j}$ according to Equation 3 from calculated values $S_{j}$ of respective variants is that variant IMTOS is more advantageous when identical weights $\left(Q_{j}=1\right)$ are used. If expert-determined weights according to the above given scale are used variant IMTOS again results as better.

Subsequently, the method was applied to three variants, i.e. including the existing technology, just with selected parameters. Table 2 shows calculation of $S_{j}$ of respective variants. Expert-determined weights have again been used. It is evident from the result of comparison that, according to basic parameters, washing machine KERMAD is a better variant. The values for comparing variants SUMMA and IMTOS are shown in Table 1.

Table 2 Parameters of rinsing and drying functions of three variants [own study]

\begin{tabular}{|c|c|c|c|c|c|c|c|c|c|}
\hline Machine designation & & KERMAD & $\begin{array}{l}\operatorname{Min} / \\
\max \end{array}$ & $\mathbf{f}^{\star} \mathbf{j}$ & $f-j$ & weight & $\begin{array}{c}\text { Sj } \\
\text { SUMMA }\end{array}$ & $\begin{array}{c}\mathrm{Sj} \\
\text { KERMAD } \\
\end{array}$ & $\begin{array}{c}\text { Sj } \\
\text { IMTOS }\end{array}$ \\
\hline Width & $(\mathrm{mm})$ & 1930 & Min & 1930 & 2300 & 0.077 & 0.077 & 0.000 & 0.000 \\
\hline Depth & $(\mathrm{mm})$ & 1410 & Min & 1345 & 2100 & 0.077 & 0.077 & 0.007 & 0.000 \\
\hline Height & $(\mathrm{mm})$ & 1660 & Min & 1660 & 2685 & 0.077 & 0.065 & 0.000 & 0.077 \\
\hline Weight of machine & $(\mathrm{kg})$ & 1050 & Min & 750 & 1050 & 0.077 & 0.000 & 0.077 & 0.038 \\
\hline Length of working space & $(\mathrm{mm})$ & 810000 & Max & 1322500 & 810000 & 0.077 & 0.000 & 0.077 & 0.053 \\
\hline Height of working space & $(\mathrm{mm})$ & 760 & Max & 800 & 700 & 0.077 & 0.000 & 0.031 & 0.077 \\
\hline Maximum weight of parts & $(\mathrm{kg})$ & 1000 & Max & 1000 & 300 & 0.115 & 0.077 & 0.000 & 0.033 \\
\hline Degreasing bath & ( & 800 & Max & 800 & 250 & 0.077 & 0.070 & 0.000 & 0.077 \\
\hline Temperature of bath & $\left({ }^{\circ} \mathrm{C}\right)$ & 65 & Max & 65 & 60 & 0.077 & 0.077 & 0.000 & 0.000 \\
\hline Degreasing pressure & (bar) & 4.6 & Max & 6 & 5 & 0.115 & 0.000 & 0.077 & 0.077 \\
\hline Power input of pumps & $(\mathrm{kW})$ & 5.5 & Min & 4 & 6 & 0.077 & 0.000 & 0.077 & 0.000 \\
\hline Power input of heating bodies & $(k W)$ & 18 & Min & 9 & 18 & 0.077 & 0.026 & 0.077 & 0.000 \\
\hline
\end{tabular}

\subsection{Evaluation of industrial washing machines using methods of investment decision making}

Main economic factors will be based on parameters connected with operation of the washing technology. Two basic parameters will be evaluated: consumption of electric energy (or power input of the washing technology) and volume of the degreasing bath in the washing technology. Main requirement for operation parameters is washing capacity of the new washing technology. Evaluated operation-economic requirements will be costs of washing of the new washing technology, i.e. costs of components washing that will subsequently be utilized in economic evaluation. In addition, costs connected with starting up the washing technology, i.e. with heating up the washing bath to operation temperature, will be evaluated. For calculation of these costs, time of heating will have to be calculated first. Subsequently, time of heating the washing bath multiplied by price of electric energy will be calculated and, thus, costs of heating partial washing and rinsing baths will be obtained following the $A B C$ costing principle [10].

For evaluation of choice of the new washing technology, it is necessary to first determine and calculate the sum of purchase investments by summing up all costs connected with activation of the new washing technology. Moreover, operation costs connected with operation of the new washing technology should be determined (see Table 3). Finally, purchase of the new washing technology will be economically evaluated using the discounted payback period. Determination of costs of washing a single component in the new washing technologies have proved to be difficult as exact residence time of one washing and rinsing bath is not known and practical tests have not been carried out. 
Table 3 Calculation of costs of washing single component of compared washing technologies [own study]

\begin{tabular}{|r|r|r|r|}
\hline Item / Manufacturer and technology & SUMMA & KERMAD & IMTOS \\
\hline Costs of washing (chemistry, water, etc.) of one component (CZK/piece) & 0.81 & 1.46 & 0.81 \\
\hline Costs of washing (el. energy) of one component (CZK/piece) & 0.04 & 0.05 & 0.04 \\
\hline Costs of rinsing (bath) of one component (CZK/piece) & 0.70 & N/A & 0.59 \\
\hline Costs of rinsing (el. energy) of one component (CZK/piece) & 0.01 & N/A & 0.01 \\
\hline Costs of drying of one component (CZK/piece) & 0.03 & N/A & 0.04 \\
\hline Total costs of pre-treatment per one component (CZK/piece) & 1.59 & 1.51 & 1.48 \\
\hline
\end{tabular}

Costs of starting up the washing technology have been evaluated using technical data from price offers of the respective suppliers. The price per $1 \mathrm{~kW}$ of electric energy of $4 \mathrm{CZK} / \mathrm{kWh}$ was used in calculating costs of heating the washing and rinsing baths. The following parameters have been evaluated: time of heating up the degreasing bath, time of heating up the rinsing bath, price of heating the degreasing bath, price of heating the rinsing bath. The most efficient heating of the degreasing and rinsing baths has been found for the washing technology of firm IMTOS where total costs of heating are $97.86 \mathrm{CZK}$. On contrary, the worst efficiency has been found for the washing technology of firm KERMAD that is by $60 \%$ more expansive in comparison with firm IMTOS, i.e. $156.57 \mathrm{CZK}$ for heating the washing bath. The washing technology of firm SUMMA is, concerning efficiency of heating the washing and rinsing baths, by $20 \%$ more expansive than the washing technology of firm IMTOS, i.e. $117.43 \mathrm{CZK}$ for heating the washing and rinsing baths. Resulting efficiency of the washing technology IMTOS is given by combination of power input of heating bodies and volume of the baths that are lower compared with the competitors. The source for determination of purchase costs of the investment is price offers. In the case of purchasing the new washing technology, this concerns items of the price offer shown in Table 4.

Table 4 Purchase costs of washing technologies [own source]

\begin{tabular}{|c|r|r|r|r|r|}
\hline Supplier & \multicolumn{1}{|c|}{ SUMMA } & \multicolumn{2}{|c|}{ KERMAD } & \multicolumn{2}{|c|}{ IMTOS } \\
\hline Item / Currency & Price in CZK & Price in EUR & Price in CZK & Price in EUR & Price in CZK \\
\hline Degreasing & 561000 & 32439 & 830438 & 28530 & 730368 \\
\hline Filtration, $\mu \mathrm{m}$ & 0 & 4030 & 103168 & 4178 & 106957 \\
\hline Oil separator & 0 & 1810 & 46336 & 3811 & 97562 \\
\hline Rinsing & 127850 & N/A & N/A & 0 & 0 \\
\hline Drying & 47500 & N/A & N/A & 6026 & 154266 \\
\hline Accessories & 79150 & 3010 & 67000 & 4200 & 120000 \\
\hline Other & 0 & & 18000 & 3300 & 99000 \\
\hline Total price of machine & 815524 & 41289 & 1074998 & 50074 & 1296894 \\
\hline
\end{tabular}

Table 4 above shows the lowest purchase costs of the washing technology of firm SUMMA.

The discounted payback period (DPP) tells us within how many years the investment expenditures return from cash flows recalculated to their current value. The discounted payback period is determined as $d$ for which the Equation 4 is valid [11]:

$$
K V=\sum_{t=1}^{d} \frac{P_{t}}{(1+r)^{t}}
$$


where: $d$ - discounted payback period, $P_{t}$ - expected monetary income in the year $t, K V$ - capital expenditures, $r$ - discount rate for recalculating future cash flows of the investment to their current value (WACC). The following items have been used in the calculation: IN washing technology, annual income $\mathrm{Zn}$, depreciation On, total annual income + depreciation, total annual discounted income. The result is shown in Figure 1.

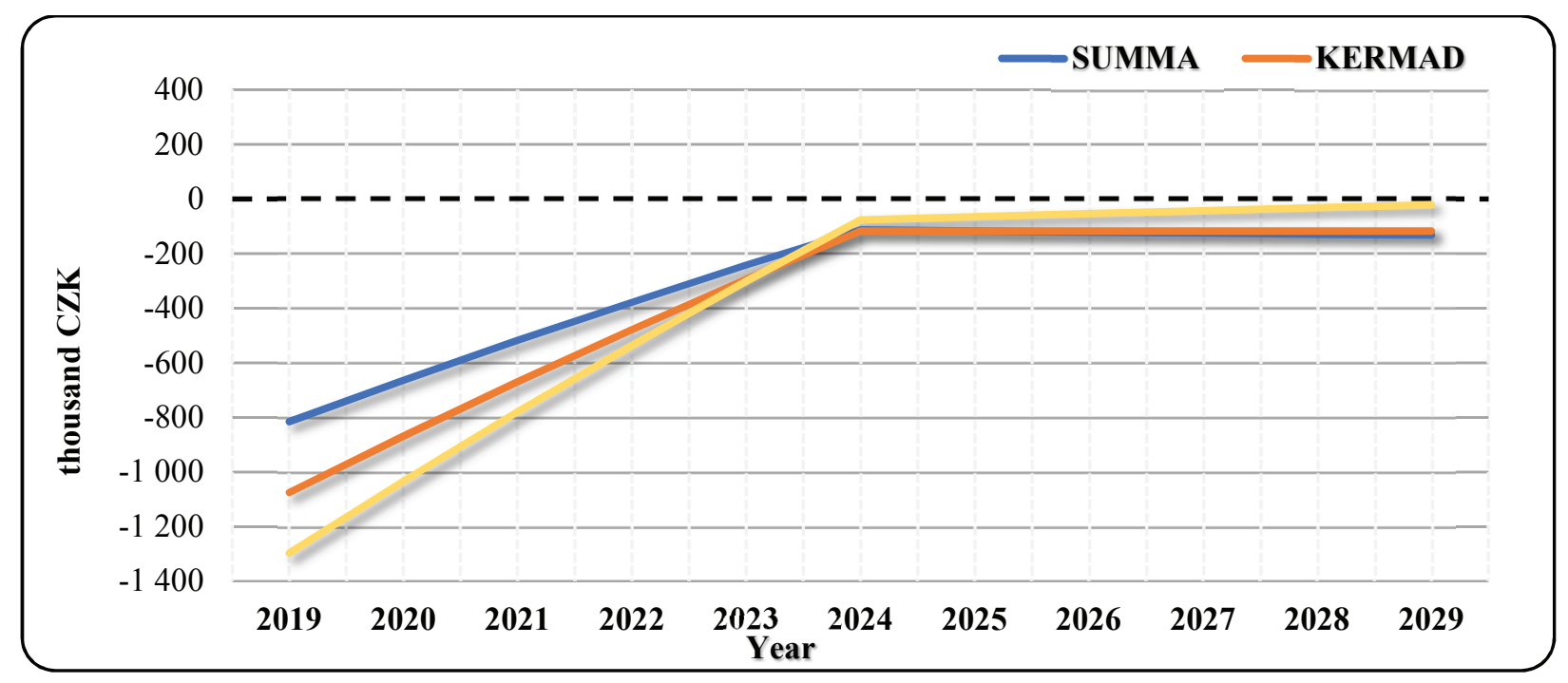

Figure 1 Discounted payback period of three variants

The discounted payback period of the washing technologies has been calculated using equation 4 . The value of $4 \%$ has been used as discount rate based on the current interest rate and the rate of risk. Based on the evaluated discounted payback period, we have arrived at the fact that the shortest payback period, with discounted income, is that of the washing technology of firm IMTOS. This is also the only washing technology for which the investments return if we take the factor of time into account. Unfortunately, however, the payback period is longer than 10 years, namely it is 12 years, and this time is limiting concerning the service life of the washing technology.

The evaluation of calculated costs of the process of pre-treatment per one component has resulted in the fact that the cheapest washing technology is that of firm IMTOS; here, the total costs of washing of one component are $1.48 \mathrm{CZK}$; the second is the washing technology of firm KERMAD; here, the total costs of the process of pre-treatment of one component are $1.51 \mathrm{CZK}$; and the third is the washing technology of firm SUMMA with total costs of the process of pre-treatment of one component of $1.59 \mathrm{CZK}$.

\section{CONCLUSION}

The evaluation of variants using the multi-criteria approach has encountered, in this case, incomplete information and impossibility of comparing all variants under the same conditions. It follows from the results of method VIKOR, comparing the washing machines of firms SUMMA and IMTOS, that technology IMTOS is the closest to an ideal solution. When comparing just the basic parameters, technology KERMAD results better. However, it should be mentioned that, for a metallurgical enterprise, economic parameters are more important than comparable parameters of the selected washing technologies.

The economic analyses clearly show that the best-evaluated supplier was firm IMTOS with the washing technology PT-PRO-3HP-MV2A which proved to be the best in seven of nine criteria; there is, therefore, no doubt that this washing technology is the most efficient replacement for the existing washing technology KERMAD K3V. Hence, the result is the fact that the best washing technology which represents the most efficient replacement for the existing washing technology KERMAD K3V is the washing technology PT-PRO- 
3HP-MV2A of firm IMTOS which did the best in all evaluated parameters, except for evaluation of purchase costs. However, even in evaluation of purchase costs, it took the second place from the three evaluated suppliers.

\section{ACKNOWLEDGEMENTS}

The work was supported by the specific university research of the Ministry of Education, Youth and Sports of the Czech Republic in VSB - Technical University of Ostrava No. SP2019/42.

\section{REFERENCES}

[1] STRAKA, Martin, MALINDZAKoVA, Marcela, TREBUNA, Peter, ROSOVA, Andrea, PEKARCIKOVA, Miriam, FILL, Maroš. Application of Extendsim for improvement of production logistics' efficiency. International Journal of Simulation Modelling. 2017. vol. 16, no. 3, pp. 422-434.

[2] STRAKA, Martin. Alfa, a.s. distribution logistics system. Acta Montanistica Slovaca. 2010. vol. 15, no. special issue, pp. 34-43.

[3] TOMEK, Gustav a Věra VÁVROVÁ. Řizení výroby a nákupu. Praha: Grada, 2007. ISBN 978-80-247-1479-0.

[4] MARTINOVIČOVÁ, Dana, Miloš KONEČNÝ a Jan VAVŘINA. Úvod do podnikové ekonomiky. Praha: Grada, 2014. ISBN 978-80-247-5316-4.

[5] VALACH, Josef a kol. Investiční rozhodování a dlouhodobé financování. Praha: Ekopress, 2010.

[6] SAMOLEJOVÁ, A., FELIKS, J., LENORT, R., BESTA, P. A Hybrid Decision Support System for Iron Ore Supply. Metalurgija, January-March 2012, vol. 51, no. 1, pp. 91-93. ISSN 0543-5846.

[7] OPRICOVIC, Serafim a Gwo-Hsiung TZENG. Compromise solution by MCDM methods: A comparative analysis of VIKOR and TOPSIS. European Journal of Operational Research. 2004, vol. 156, no. 2, pp. 445-455. ISSN 0377-2217.

[8] CHALÚPKOVÁ, Eva a Jiři FRANEK. Comparison of the AHP and ANP approach to Investment Decision Making. In VOJÁČKOVÁ, H. Proceedings of the 31st International Conference Mathematical Methods in Economics 2013, Vol I and II. Jihlava: College of Polytechnics Jihlava, 2013, pp. 303-308. ISBN 978-80-87035-76-4.

[9] BESTA, P. Removal of zinc the blast-furnace process. Przemysl chemiczny. 2016. vol. 95, no. 9, pp. 1752-1755.

[10] KUTÁČ, J., P. BESTA, T. KUTÁČ et al. Use of ABC calculations in metallurgical production. In METAL 2016: 25th International Conference on Metallurgy and Materials. Ostrava: TANGER, 2016, pp. 1906-1911.

[11] ČIŽINSKÁ, Romana. Základy finančniho ř́zení podniku. Praha: Grada Publishing, 2018. ISBN 978-80-271-01948. 